\title{
NEW RECORDS TO THE BRYOFLORA OF THE E SLOPE OF MT. KENYA
}

\author{
Itambo Malombe1, Muiruri Patel' ${ }^{1}$, George K. Mugambi ${ }^{3}$ \\ \& Tamás Pócs ${ }^{2 *}$
}

${ }^{1}$ Cryptogamic Herbarium of the National Museum of Kenya, Nairobi, P.O. Box 45166 Nairobi-00100, Kenya; '2Institute of Biology, Eszterházy Károly Catholic University, Eger, Pf. 43, Hungary, H-3301; ${ }^{3}$ Department of Biological Sciences, Meru University of Science and Technology, P.O. Box 972-60200, Meru, Kenya;

*E-mail: pocs.tamas33@gmail.com

\begin{abstract}
The first author studied the bryophyte communities on the East slope of Mt. Kenya through the forest belt between 1600 and 3000 m elevations. Seven sampling plots were selected at each $200 \mathrm{~m}$ altitudinal interval. At each sampling plot microclimate data measurements were carried out for six months between July and December 2020 using dataloggers and the composition of epiphyllous communities was studied in details with special reference to the host plants. Tamás Pócs and his team (Bence Együd, Judit Havasi and Mária Szegedi) joined to this research during the August of 2021, to help in further collection and identification work. The collected specimens are deposited in the herbaria of EA and EGR. Majority of the collections have already been identified. The discovery of the only mainland African occurrences of the Lemurian Microlejeunea inflata and Leptodon fuciformis are outstanding results. Other species are new for Kenya: Cololejeunea platyneura, Cyclodyction subbrevifolium, Diplasiolejeunea deslooveri, Fissidens intramarginatus and Telaranea coactilis. The last author visited the same sites 2004 with his late wife, Sarolta Czímer, guided by Min S.Chuah-Petiot from Nairobi University and from their collection Gemmabryum subapiculatum, Orthotrichum denticulatum, Lophocolea fragrans and Lophocolea muricata proved to be new to Kenya.
\end{abstract}

Keywords: Africa, endemism, Kenya, Lemurian element

\section{INTRODUCTION}

Mount Kenya (Kirinyaga) is the highest mountain in Kenya and the second highest of Africa, with its 5199 m elevation. It lies just at the $\mathrm{S}$ side of Equator and was formed by tertiary volcanic activity. Protected as a national park, since 1949, spreading over $120 \mathrm{~km}$ 
diameter, at 71500 ha area, quite isolated by the surrounding lowland (Bennun and Njoroge 2000).

Mount Kenya attracted many botanists but its bryological exploration started relatively late. The first bryophyte collectors were probably R. E. and Th. C. E. Fries in 1922 (Vanden Berghen 1951). Three later publications contained the majority of records. 0.Hedberg's afroalpine collections (including many records from Mt. Kenya) were identified and pulished by Potier de la Varde (1955) and by S. Arnell (1956). M. S. Chuah-Petiot carried out intensive fieldwork in the mountains for several years. She reported 194 bryophyte species of which 38 species were new to Mt. Kenya and 30 others for the whole country (Chuah-Petiot 1995). Apart from these many publications contain scattered records from the mountains.

The first author made a comprehensive documentation of the epiphytic bryophyte communities along the Chogoria Trail, located SW of Meru town, on the East, windward slope of Mt. Kenya. The permanent sampling plots (PSPs) were spread through the whole forest belt between 1600 and $3000 \mathrm{~m}$ elevations, at each approximately $200 \mathrm{~m}$ altitudinal interval. Mugambi and Patel were instrumental in site selection and description.

The sampling plots are marked by the following abbreviations:

Nt: $1640 \mathrm{~m}$. Degraded submontane rainforest dominated by Anthocleista grandiflora-Diospyros abyssinica, mixed with Strombosia scheffleri, Agelaea pentagyna and Allophylus abyssinicus.

Ch1: $1800 \mathrm{~m}$. S $00^{\circ} 13.95^{\prime}$, E $37^{\circ} 32.11^{\prime}$. Disturbed montane rainforest dominated by Zanthoxylum gilletii - Harungana madagascariensis, with Tabernaemontana stapfiana, Elaeodendron buchananii, Xymalos monospora and Strombosia scheffleri.

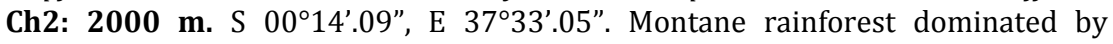
Anthocleista grandiflora, Cassipourea malosana, Macaranga kilimandscharica, intermixed with Podocarpus latifolius and Xymalos monospora.

Ch3: 2200 m. S $00^{\circ} 14^{\prime} 09^{\prime \prime}$, E $37^{\circ} 33^{\prime} .05^{\prime \prime}$.'Montane rainforest dominated by Kuloa usambarensis, Afrocarpus falcatus, Cassipourea malosana, mixed with Galiniera saxifraga, Xymalos monospora and Podocarpus latifolius.

Ch4: 2400 m. S $00^{\circ} 12^{\prime} 29^{\prime \prime}$, E $37^{\circ} 30^{\prime} 02^{\prime \prime}$. Upper montane rainforest dominated by Afrocrania volkensii, Schefflera volkensii, mixed with Nuxia congesta, Cassipourea. malosana and Podocarpus latifolius.

Ch5: 2600 m. S 00¹1'23”, E 37²8’34”. Bamboo (Yushania alpina) forest with scattered and emergent Nuxia congesta trees.

Ch6: 2800-2950 m. S $00^{\circ} 10^{\prime} 04^{\prime \prime \prime}$, E $37^{\circ} 28^{\prime} 08^{\prime \prime}$. Juniperus procera forest intermixed with Afrocarpus falcatus, Hagenia abyssinica and Yushania alpina.

During our recent trip we collected only in the plots No. Ch2, Ch3, Ch4 and Ch6 and at $2100 \mathrm{~m}$, between Ch2 and Ch3: Ch2.2 and at $2300 \mathrm{~m}$, between Ch3 and Ch4: Ch3.2. The spot numbers with boldface are used in the enumeration of records. 


\section{MATERIAL AND METHODS}

Tamás Pócs and his team (Bence Együd, Judit Havasi and Maria Szegedi) joined to this research during the August of 2021, to help in the collection and identification work. Pócs visited the same route earlier, in February 2004 with his wife, Sarolta Czímer, guided by Min Chuah-Petiot from Nairobi University. The collected and already identified specimens from both collections are deposited in the herbaria of EA and EGR.

\section{RESULTS}

The records new to Kenya or the whole of continental Africa, according to Wigginton (2018) and to O'Shea (2006), are enumerated below:

\section{Liverworts}

Cololejeunea platyneura (Spruce) A.Evans occurs between 2000 and $3000 \mathrm{~m}$ in Guinea, Sierra Leone, Nigeria, DR Congo, Rwanda, Tanzania, Malawi and Madagascar (Fischer 2013, Wigginton 2018). Epiphyllous in montane forests. - Malombe et al., at 2200 (Ch3) and $2900 \mathrm{~m}$ (Ch6).

Diplasiolejeunea deslooveri Vanden Berghen distributed in DR Congo, Rwanda, Kenya, Zimbabwe, Mozambique, South Africa.

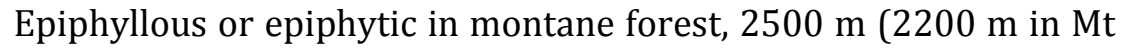
Kenya, Ch3).

Lophocolea fragrans (Moris et De Not.) Gottsche, Lindenb. et Nees. is a species with very scattered (or unknown) distribution from the oceanic and Mediterranean parts of Europe, from Costa Rica, East China and from a few localities in Africa (Paton 1999, Wigginton 2018). Not yet known from Kenya. - Pócs \& Chuah-Petiot 04003/A, at $2300 \mathrm{~m}$, corticolous, the same locality, as Ch3.2.

Lophocolea muricata (Mitt.) Schiffn. is a Pantropical-oceanic temperate species widespread in Africa but hitherto was unpublished from Kenya (Grolle 1959, Wigginton 2018). Pócs \& Chuah-Petiot $04010 / \mathrm{F}$, at $2180 \mathrm{~m}$, on decaying log, the same, as Ch3.

Microlejeunea inflata Steph. (Figure 1). KENYA: Ch4, Epiphyllous on Podocarpus latifolius leaves.The extension of its known 
distribution to mainland Africa is remarkable. The species hitherto was known only from the Indian Ocean Islands (Grolle 1995). Good illustration of the species is done by Pócs (2002: 18, fig. 6). Type: from MADAGASCAR: without closer indication of locality: Forsyth Major 1000, in Stephani 1915), later published from the Antsiranana Prov., Réserve spéciale de Manongarivo (Pócs and Geissler 2002) furthermore there are three unpublished records from Madagascar: Toamasina Prov., Maromizaha forest $S$ of Andasibe National Park at 1200 m, epiphyllous on Pandanus leaves, S. Pócs 9890/CL; Antsiranana Prov., Marojezy National Park, 7801050 and 1830 m, epiphyllous, Pócs et al. 90113/EC and 90114/KA. From COMORO Islands: Ndzouani Island, first reported by Pócs (1993, confirmed by Grolle 1995), from Mayotte Island also became known (Chongui peak, 300-500 m, epiphyllous, Pócs \& Magill 9287/AD, det. Grolle; Dapani, Réserve Forestière des Crêtes, 110$210 \mathrm{~m}$, on roots, S. \& T. Pócs 05080/G, NW du village Chembényoumba, $34 \mathrm{~m}$, on roots, S. \& T.Pócs 05090/G (all Mayotte records unpublished). It is known from many localities in RÉUNION Island (fully enumerated by Ah-Peng et al. 2010). New to the SEYCHELLES, Mahé Island, Morne Seychellois Nat. Park, summit ridge of Morne Blanc in mossy elfin forest dominated by Northea seychellarum and Roscheria melanochaetes. 600-667 m, epiphyllous. Pócs 00102/Q and 01539/R and Mahé Island, Grand Bois, on leaves of Vateriopsis seychellarum, J. Gerlach s.n. 2 Aug. 2002, det. Pócs.

Telaranea coactilis (Spruce) J.J.Engel \& G.L.Merr. (Figure 2). Among other bryophytes. Earlier this species was treated as Arachniopsis diacantha (Mont.) Howe, with tropical AfricanAmerican distribution (Gradstein et al. 1984). Engel \& Smith Merrill (2004) in their revision of genus Telaranea distinguished two species formerly known as Arachniopsis diacantha under the binomials of Telaranea diacantha (Mont.) Engel \& Merr. and Telaranea coactilis (Spruce) Engel \& Merr., giving good distinguishing characters between the two in the shape and size and cell number leaf segments. Although both species were recorded from Africa, T. coactilis was not known from Kenya (Wigginton 2018). Ch3, on decaying log in the cushion of Syrrhopodon asper Mitt. 


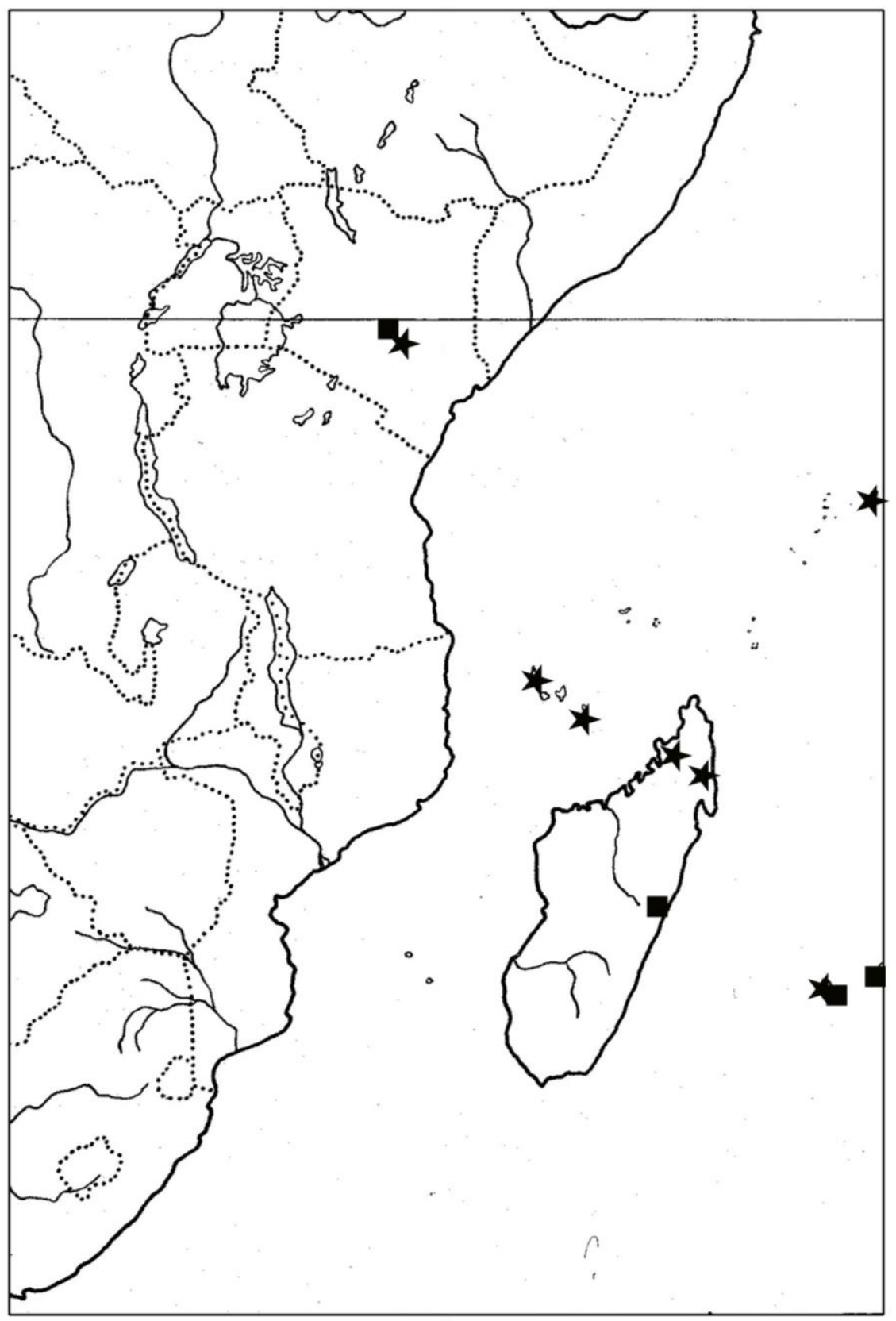

Figure 1. Distribution of Microlejeunea inflata Steph. (asterisk) and of Leptodon fuciformis (Brid.) Enroth. 


\section{Mosses}

Cyclodictyon subbrevifolium Broth. (Figures 3-4). A species described and till now known only from Tanzania, Mt.Kilimanjaro along the Marangu Route at about 2800 m. New to Kenya: Ch3. Typical characters are the broad ovate leaves with acuminate apex and subentire or entire 2-seriate margin, with obsolete teeth (Demaret and Potier de la Varde 1951).

Fissidens intramarginatus (Hampe) A.Jaeger. An Afro-American disjunct widespread in tropical Africa, but new to Kenya: Ch3, on decaying log. The specific characters are the limbidia extending the whole length of vaginal laminae and the pluripapillose leaf cells with low and blunt papillae (Bruggeman-Nannenga 2006).

Gemmabryum subapiculatum (Hampe) J. R. Spence \& H. P. Ramsay. Syn.: Bryum subapiculatum Hampe. A cosmopolitan species hitherto known in East Africa only from Tanzania (Bizot et al. 1979), new to Kenya. On shady rock in bamboo forest, Pócs \& Chuah-Petiot 04008/P, same locality as Ch5.

Leptodon fuciformis (Brid.) Enroth (See figures 1 and 5-8). The species was hitherto considered to be an Indian Ocean Islands endemic known under the name of Pinnatella fuciformis (Brid.) Touw. and known only from Madagascar, Mauritius and Réunion. It is related to Leptodon smithii (Hedw.) F.Weber \& D.Mohr, widespread also in the drier montane forests of continental Africa. But well differs by the hanging habit bipinnately branching at its lower and remotely and irregularly branched upper part with tapering branches which are not inrolled even in dry state (Enroth 1992). Ch6. Epiphyte hanging from Juniperus procera twigs.

Orthotrichum denticulatum Lewinsky. A rare East African montane epiphyte only known from Ethiopia, Rwanda and Tanzania occurring between 1700 and $2700 \mathrm{~m}$.It is recognized by ovato-lanceolate leaves with broadly recurved margin and hyaline, denticulate apex, strongly 8-ribbed theca with cryptopore stomata. (Lewinsky 1978). New to Kenya: Pócs \& Chuah-Petiot 04008/A (same as Ch5), on bamboo (Yushania alpina) twigs. 

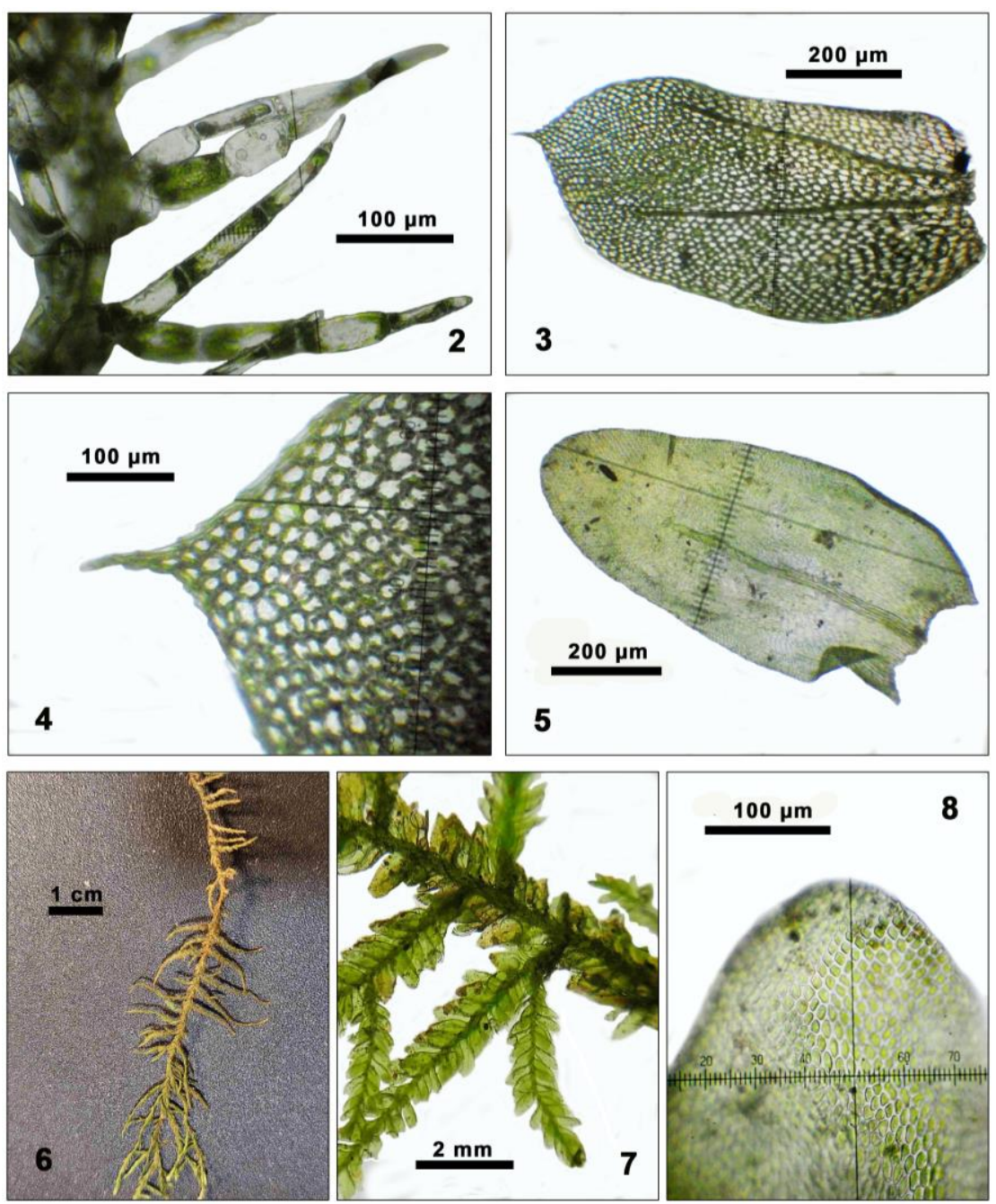

Figure 2. Telaranea coactilis (Spruce) J.J.Engel \& G.L.Merr., part of shoot, dorsal, view (from T. Pócs et al. Ch3.CA). Figures 3-4. Cyclodictyon subbrevifolium Broth., leaf and leaf apex (from Ch3.A). Figures 5-8. Leptodon fuciformis (Brid.) Enroth, leaf, habit of hanging specimen, shoot with side branches and leaf apex (from Ch.6A).

\section{DISCUSSION}

As from the above examples can be seen, even the best investigated areas of Kenya can provide new records, what calls attention to the still inadequately searched Kenyan bryoflora, waiting for new 
discoveries. The enumerated bryophytes are either widespread but overlooked taxa or rare species hitherto known only from their type locality or new to the continent. Also, some Lemurian (mostly on Indian Ocean islands distributed) species, atlhough are concentred in mainland Africa to the Eastern Cristalline Arc mountains, can occur also on some isolated volcanoes in Kenya, like Microlejeunea inflata and Leptodon fuciformis. In particular, the study and dicovery of epiphyllous bryophytes from the entire range of afromontane and montane forests in Mt Kenya lays a formidable baseline for monitoring biodiversity shifts underscored by the impacts of climate change.

Acknowledgement - The first author thanks the National Geographic Society for the generous funding on the exploration of the first comprehensive epiphyllous bryophyte diversity in Mt Kenya. He also humbly acknowledges facilitation by the National Museums of Kenya, Meru University of Science and Technology, Kenya Forest Service, National Council for Science, Technology and Innovation and Kenya Wildlife Service. The local community representatives through the Community Forest Association are also recognised for their active participation during the field studies. The second author and his team are very grateful to Dr. Itambo Malombe, organising transport and guiding to his permanent research plots in three regions of Kenya and to Dr. Min Chuah-Petiot organizing a course at Nairobi University and within its frame taking Tamás Pócs and his wife to Mt. Kenya along the Chogoria trail. The authors acknowledge the careful review of the paper by Dr. Andrea Sass-Gyarmati and Dr. Sándor Orbán.

\section{REFERENCES}

Ah-Peng, C., Bardat, J., Stamenoff, P., Hedderson, T. A. J. \& Strasberg, D. (2010). Bryophytes de l'ile de La Réunion: diversité, endemicité et conservation. Cryptogamie, Bryologie 31: 241-270.

ARnELL, S. (1956). Hepaticae collected by O. Hedberg et al. on the East African mountains. Arkiv för Botanik 3(16): 517-562.

Bennun, L. \& NJoRoge, P. (2000). Important bird areas in Kenya. Ostrich 71(12):164-167. https://doi.org/10.1080/00306525.2000.9639900

Bizot, M. \& Pócs, T. (1979). East African Bryophytes III. Acta Botanica Academicae Scientiarum Hungaricae 24: 58-64.

Bruggeman-NANnEnGa, M.A. (2006). Bryophyte flora of Uganda. 6. Fissidentaceae (Part 1) Journal of Bryology 28: 53-62. https://doi.org/10.1179/174328206X90422

Chuah-Petiot, M.S. (1995). Data to the bryoflora of Mount Kenya, Kenya. Tropical Bryology 10: 41-53.

Demaret, F. \& Potier de la VARDE, R. (1951). Les espèces africaines de genre Cyclodictyon Mitt. Bulletin du Jardin Botanique de l'État 31: 11-59. 
https://doi.org/10.2307/3666809

Engel, J.J. \& Smith Merrill, G.L. (2004). Austral Hepaticae 35: A taxonomic and phylogenetic study of Telaranea (Lepidoziaceae) with a monograph of the genus in temperate Australasia and commentary on extra-Australasian taxa. Fieldiana Botany 44: 1-261. https://doi.org/10.3158/0015-0746(2004)44[1:AHATAP]2.0.C0;2

Enroth, J. (1992). Corrections to Cryptoleptodon, Forsstroemia and Leptodon (Leptodontaceae, Musci). Journal of the Hattori Botanical Laboratory 71: 7582.

FisCHER, E. (2013). Liverworts and Hornworts of Rwanda. Abc taxa 14: 1-541.

Gradstein, S.R., Pócs, T. \& VÁŇA, J. (1984). Disjunct Hepaticae in tropical America and Africa. Acta Botanica Hungarica 29: 127-171.

Grolle, R. (1959). Beitrag zur Kenntnis der afrikanischen Lophocoleen. Transactions of the British Bryological Society 3: 582-598. https://doi.org/10.1179/006813859804829171

Grolle, R. (1995). The Hepaticae and Anthocerotae of the East African Islands. An annotated catalogue. Bryophytorum Bibliotheca 48: 1-178.

LEWINSKY, J. (1978). The genus Orthotrichum Hedw. (Musci) in Africa South of the Tropic of Cancer. Botanisk Tidsskrift 72(2-3): 61-84.

O'SHEA, B.J. (2006). Checklist of the mosses of sub-Saharan Africa (version 5, 12/06). Tropical Bryology Research Reports 6: 1-252.

Paton, J.A. (1999). The liverwort flora of the British Isles. Harley Books, Colchester, $626 \mathrm{pp}$.

Potier DE LA VARDE, R. (1955). Mousses récoltées par M. le Dr. Olov Hedberg, en Afrique orientale, au cours de la mission suédoise. Arkiv för Botanik 3(8): 125204.

Pócs, T. (1993). New or little known epiphyllous liverworts, IV. Two new Cololejeuneoideae from the Comoro Archipelago. Journal of the Hattori Botanical Laboratory 74: 45-57.

Pócs, T. (2002). East African Bryophytes XVIII. Two new Lejeuneaceae (Hepaticae) from the Aberdare Mountains (Kenya). Polish Botanical Journal 47(1): 11-20.

Pócs, T. \& GeIsSler, P.† (2002). The bryophytes collected in the Réserve Spéciale de Manongarivo, Madagascar. (Chapter 3.) In: GauTiER, L. \& Goodman, S.M. (eds.): Inventaire Floristique et Faunistique de la Réserve Spéciale de Manongarivo (NW Madagascar). Boissiera 59: 41-76.

Stephani, F. (1915). Species hepaticarum 5. George \& Cie, Genève \& Bâle, pp. 705832.

VANDEN BERGHEN, C. (1951): Note sur quelques hépatiques récoltées par R.E. et T. Fries en 1922. au Mont Kénia. Svensk Botanisk Tidskrift 45(2): 362-367.

WigGinToN, M.J. (2018). Checklist and distribution of the liverworts and hornworts of sub-Saharan Africa, including the East African Islands (edition 4). Tropical Bryology Research Reports 9: 1-138.

(submitted: 30.10.2021, accepted: 21.12.2021) 